\title{
36 \\ PELAYANAN SOSIAL BAGI REMAJA PUTUS SEKOLAH
}

\author{
Oleh: \\ Elita Metica Tamba, Hetty Krisnani, \& Arie Surya Gutama
}

Email:

(elitametica@yahoo.com; budimtunpad@gmail.com; ariesurya_gutama@yahoo.com)

\begin{abstract}
ABSTRAK
Setiap anak Indonesia berhak mendapatkan pendidikan untuk pengembangan potensi, minat dan bakat dirinya agar mereka kelak dapat menjadi penerus bangsa yang memiliki kemampuan intelektual sehingga dapat dijadikan sumber daya manusia yang berpotensi dalam memimpin bangsa dan negara kearah yang lebih baik. Namun banyak faktor yang akhirnya membuat anak-anak Indonesia mengalami putus sekolah. Faktor-faktor yang menyebabkan remaja putus sekolah adalah ekonomi keluarga, kurangnya kemampuan dan minat remaja dalam mengikuti pendidikan di sekolah, kondisi tempat tinggal remaja, pandangan masyarakat terhadap pendidikan, adat istiadat dan ajaranajaran tertentu. Remaja putus sekolah merupakan masalah sosial yang harus mendapatkan perhatian khusus, karena dampak yang ditimbulkan tidak lagi hanya dirasakan oleh individu remaja itu sendiri, tetapi juga oleh masyarakat. Dampak yang ditimbulkan yaitu pengangguran, kriminalitas, kemiskinan dan kenakalan remaja. Diperlukan upaya penanganan remaja putus sekolah untuk mengurangi dampak negatif yang mereka timbulkan. Dalam upaya mengurangi remaja putus sekolah, diperlukan kerjasama dari berbagai pihak, baik dari pemerintah maupun masyarakat. Salah satu upaya yang dilakukan adalah dengan memberikan pelayanan sosial. Pelayanan sosial tersebut bertujuan agar remaja putus sekolah tetap mendapatkan pendidikan di luar sekolah yang dapat dijadikan bekal untuk memperoleh pekerjaan sehingga mereka dapat memenuhi kebutuhannya secara mandiri. Pelayanan sosial yang diberikan tentunya harus sesuai dengan kebutuhan remaja putus sekolah. Pelayanan sosial yang dapat diberikan yaitu berupa pembinaan bagi remaja putus sekolah melalui bimbingan. Bimbingan yang diberikan yaitu bimbingan mental agama, bimbingan sosial dan fisik, bimbingan keterampilan dan Praktek Belajar Kerja (PBK).

Kata kunci: Pelayanan Sosial, Pekerjaan Sosial, Remaja Putus Sekolah
\end{abstract}

\section{PENDAHULUAN}

Putus Sekolah dipandang sebagai masalah pendidikan dan sosial yang amat serius selama beberapa dekade terakhir ini. Dengan meninggalkan sekolah sebelum lulus, banyak individu putus sekolah yang tidak mendapatkan pendidikan yang cukup sehingga kesejahteraan ekonomi dan sosialnya menjadi terbatas sepanjang hidup sebagai orang dewasa. Pendidikan diperlukan dalam upaya pembinaan dan pengembangan potensi, minat dan bakat generasi muda. Oleh sebab itu, remaja harus mendapatkan perhatian khusus dalam pendidikan dan partisipasi dalam masyarakat agar mereka dapat meneruskan perjuangan bangsa dan pembangunan nasional dengan cara mengembangkan kreativitas mereka melalui pendidikan.

Setiap individu tidak terkecuali remaja tentunya ingin memperoleh pendidikan agar dapat mencapai cita-cita. Diperlukan usaha, sarana dan prasarana untuk memperoleh pendidikan. Namun kenyataannya untuk memenuhi kondisi tersebut tidak mudah dengan berbagai kendala dan keterbatasan yang ada pada sebagian individu, keluarga maupun masyarakat. Ketika kendala tersebut 
tidak dapat diselesaikan maka akan menyebabkan remaja putus sekolah. Padahal sekolah merupakan salah satu sarana untuk memperoleh pendidikan, pengetahuan dan pengalaman yang menunjang kehidupan di masa mendatang.

Kusumah (2008) mengatakan bahwa permasalahan remaja putus sekolah merupakan persoalan yang besar dan serius. Persoalan ini tidak hanya sekedar ketidakberdayaan atau hanya putus sekolah tetapi persoalan berkurangnya sumber daya manusia yang pada saatnya tidak sanggup berbuat apa-apa, karena tidak dipersiapkan untuk menghadapi tantangan. Keadaan ini nantinya akan mengancam kelangsungan hidup dan masa depan bangsa Indonesia ketika jutaan generasi penerus bangsa mengalami putus sekolah. Selain itu juga, permasalahan remaja putus sekolah akan menimbulkan berbagai akibat, karena mereka tidak memiliki bekal yang menunjang hidup mereka saat menjadi dewasa. Hal ini akan menimbulkan tidak tercapainya cita-cita mereka, sehingga timbul ketidakberdayaan remaja, perasaan rendah diri dan terasingkan dari lingkungan sosialnya.

Diperkirakan setiap tahun remaja putus sekolah terancam haknya untuk terus bersekolah. Berdasarkan data BPS 2011, jumlah anak putus sekolah yang berumur 7-17 tahun sebesar 2,91 persen, artinya setiap 1000 orang penduduk usia 7-17 tahun, terdapat 29 anak yang putus sekolah. Setiap anak putus sekolah tersebut tersebar di berbagai provinsi di Indonesia baik di daerah perkotaan maupun perdesaan. Anak yang bertempat tinggal di daerah perdesaan lebih banyak yang mengalami putus sekolah dibandingkan anak yang berada di daerah perkotaan (http://www.bps.go.id/)

Faktor remaja putus sekolah menurut Widodo (2012:88) antara lain yaitu ekonomi keluarga, kurangnya kemampuan dan minat remaja dalam mengikuti pendidikan di sekolah, kondisi tempat tinggal remaja, pandangan masyarakat terhadap pendidikan, adat istiadat dan ajaran-ajaran tertentu. Dengan kondisi tersebut, akhirnya saat ini banyak remaja putus sekolah yang terpaksa harus bekerja dengan kemampuan seadanya, untuk membantu perekonomian keluarga. Namun demikian, sejalan dengan perkembangan waktu, fenomena anak yang bekerja, tentunya banyak berkaitan dengan alasan ekonomi keluarga dan kesempatan memperoleh pendidikan serta faktor sosial dan lingkungan.

Keberadaan remaja putus sekolah perlu mendapatkan perhatian dari berbagai pihak. Remaja yang mengalami putus sekolah membutuhkan bimbingan untuk mempersiapkan mereka masuk dalam dunia kerja ataupun melanjutkan sekolahnya kembali. Seperti yang diungkapkan Santrock (2003:265), pendekatan yang bisa dipertimbangkan oleh institusi masyarakat adalah mengarahkan kembali pendidikan kejuruan agar mereka memperoleh keterampilan-keterampilan dasar yang dibutuhkan sejumlah besar pekerjaan, dan jaminan untuk bisa melanjutkan pendidikan, pekerjaan, atau pelatihan, khususnya yang berhubungan dengan program bimbingan.

Di Indonesia, pelayanan sosial yang diberikan bagi remaja putus sekolah biasanya berupa pembinaan di dalam panti. Dalam proses pembinaan tersebut, remaja putus sekolah akan diberikan bimbingan. Bimbingan-bimbingan yang diberikan antara lain: bimbingan mental agama, bimbingan sosial dan fisik, bimbingan keterampilan dan Praktek Belajar Kerja (PBK).

\section{PEMBAHASAN}

Istilah Remaja atau Adolescence berasal dari kata latin Adolescere yang artinya tumbuh ke arah kematangan (Muss,1968:4). Kematangan yang dimaksud tidak hanya berarti kematangan fisik, tetapi terutama kematangan sosial-psikologis. Arti luas dari istilah remaja saat ini mencakup kematangan mental, emosional, sosial dan fisik. Pandangan ini diungkapkan oleh Piaget dalam Hurlock (1991:206) :

Secara Psikologis, masa remaja adalah usia dimana individu berintegrasi dengan masyarakat dewasa, usia dimana anak tidak lagi merasa dibawah tingkat orang-orang yang lebih tua melainkan berada dalam tingkatan yang sama, sekurang-kurangnya dalam masalah hak... . Integrasi dalam masyarakat (dewasa) mempunyai banyak aspek efektif, kurang lebih berhubungan dengan masa puber ... . Termasuk juga perubahan intelektual yang mencolok ... . Transformasi intelektual yang khas dari cara berfikir masa remaja ini memungkinkannya untuk mencapai integrasi dalam 
hubungan sosial orang dewasa, yang kenyataannya merupakan ciri khas, yang umum dari periode perkembangan ini.

Batas usia remaja secara umum adalah berkisar antara 13 sampai 21 tahun. Sedangkan batas usia remaja sebenarnya, yaitu remaja yang ditandai dengan perubahan sikap dan perilaku atau disebut juga remaja pada fase akhir adalah antara 18 sampai 21 tahun. (Cole, 1963:25),

Putus sekolah adalah proses berhentinya siswa secara terpaksa dari suatu lembaga pendidikan tempat dia belajar. Artinya adalah terlantarnya anak dari sebuah lembaga pendidikan formal, yang disebabkan oleh berbagai faktor, salah satunya kondisi ekonomi keluarga yang tidak memadai (Musfiqon, 2007:19). Sedangkan menurut R. Iyeng Wiraputra, M.Sc. dan Drs. Adim,dkk. dalam kamus istilah pendidikan (1997 : 290), yang dimaksud dengan anak putus sekolah adalah anak yang karena satu atau alasan lain meninggalkan sekolah, tidak menyelesaikan jenjang sekolah yang telah ditentukan. Dengan pengertian tersebut maka yang dimaksud dengan remaja putus sekolah adalah remaja yang tidak menyelesaikan jenjang sekolah yang telah ditentukan karena satu atau alasan lain meninggalkan sekolah.

Banyak faktor yang menyebabkan terjadinya putus sekolah, selain faktor yang berasal dari dalam diri anak didik sendiri, seperti kemalasan dan ketidakmampuan diri, bisa juga karena faktor diluar anak didik, seperti ketiadaan biaya dan sarana pendidikan, sebagaimana menurut Baharuddin M. (1981 : 252), faktor yang menyebabkan terjadinya putus sekolah adalah faktor kependudukan, faktor ledakan usia sekolah, faktor biaya, faktor kemiskinan, faktor sarana, faktor sistem pendidikan. faktor I.Q. (Intelegensi), faktor mentalitet anak didik.

Dari faktor penyebab terjadinya putus sekolah diatas, maka kita bisa melihat bahwa ternyata penyebab putus sekolah tidaklah sederhana dan bersifat tunggal melainkan banyak faktor yang menyebabkannya. Berdasarkan pengertian remaja putus sekolah tersebut, kita bisa mengartikan bahwa yang menjadi inti persoalan remaja putus sekolah adalah ketidak mampuan, apakah itu ketidak mampuan kemampuan diri anak didik atau ketidak mampuan diluar diri anak didik.

Kondisi yang dialami oleh remaja putus sekolah menurut Combs (1973:53), yaitu:

1. Timbul rasa kecewa dan patah semangat karena terpaksa keluar dari sekolah, padahal mereka masih memiliki keinginan untuk belajar.

2. Dapat menimbulkan kemerosotan moral karena ada kekosongan dalam jiwa remaja sehingga mudah berperilaku negatif.

3. Mereka terancam menjadi buta huruf karena biasanya mereka segera mengemban tanggung jawab sosial sebagai orang dewasa (hidup berumah tangga, ikut mencari nafkah), walaupun berusaha mengembangkan diri melalui latihan-latihan.

4. Mereka kurang mampu mencapai kedewasaan sehingga kurang siap untuk berkeluarga, kurang pergaulan, kurang mandiri.

5. Masyarakat banyak dirugikan karena biasanya remaja putus sekolah dapat menimbulkan pengangguran, kriminalitas, kenakalan remaja, dan mereka tidak dapat berpartisipasi aktif dalam pembangunan masyarakat.

Remaja putus sekolah merupakan salah satu masalah sosial yang dampaknya tidak hanya dirasakan oleh dirinya sendiri, tetapi juga oleh masyarakat. Seperti yang telah diungkapkan sebelumnya, remaja putus sekolah dapat menimbulkan pengangguran, kriminalitas, kemiskinan dan kenakalan remaja. Diperlukan upaya penanganan remaja putus sekolah untuk mengurangi dampak negatif yang mereka timbulkan. Menurut Santrock (2003:265), pendekatan-pendekatan yang dapat dilakukan antara lain:

a. Mengawasi pengalaman kerja, seperti melalui pendidikan kooperatif, magang, kerja praktek, pelatihan sebelum bekerja, dan perusahaan yang dikelola oleh remaja. 
b. Layanan masyarakat dan lingkungan, termasuk layanan sukarela dan layanan bimbingan oleh remaja.

c. Mengarahkan kembali pendidikan kejuruan, dimana prinsipnya seharusnya bukan menyiapkan remaja untuk melakukan pekerjaan tertentu, namun lebih kearah memperoleh keterampilanketerampilan dasar yang dibutuhkan pada sejumlah besar pekerjaan.

d. Jaminan untuk bisa melanjutkan pendidikan, pekerjaan, atau pelatihan, khususnya yang berhubungan dengan program bimbingan (mentoring).

Pelayanan sosial merupakan salah satu upaya yang tepat untuk memperbaiki keberfungsian sosial remaja putus sekolah. Pelayanan sosial dalam arti luas adalah setiap pelayanan yang dimaksudkan untuk meningkatkan kesejahteraan sosial manusia, sedangkan dalam arti sempit ialah pelayanan yang diberikan kepada sebagian masyarakat yang kurang atau tidak beruntung (Sukoco, 1991:3). Pelayanan sosial bagi remaja putus sekolah adalah kegiatan-kegiatan atau intervensiintervensi terhadap masalah remaja putus sekolah dan dilaksananakan secara langsung dan terorganisasi serta memiliki tujuan untuk membantu remaja putus sekolah agar mampu memenuhi kebutuhan-kebutuhannya. Tujuan pelayanan sosial bagi remaja putus sekolah adalah membantu para remaja putus sekolah terlantar untuk dapat mewujudkan tujuan mereka serta memecahkan permasalahan yang mereka hadapi agar dapat memperbaiki kondisi kehidupannya secara mandiri.

Pelaksanaan pelayanan sosial bagi remaja putus sekolah merupakan suatu proses pelayanan untuk mengembalikan peranan sosial penerima manfaat sehingga mereka dapat menjalankan tugastugas kehidupannya sesuai dengan perannya. Pelayanan sosial yang berbasis lembaga atau sering dikenal dengan pelayanan sosial di dalam panti menurut Kurniasari dkk (2009:19) adalah sebagai berikut:

a. Bimbingan fisik, meliputi permakanan, kegiatan olahraga, perawatan kesehatan.

b. Bimbingan mental, meliputi:

1. pemenuhan kebutuhan akan privasi.

2. memberikan kesempatan menentukan pilihan sesuai dengan bakat dan minat penerima manfaat.

3. pemberian pelayanan pendidikan kecerdasan.

c. Bimbingan sosial, meliputi:

1. Bermain, rekreasi serta pemanfaatan waktu luang

2. Kegiatan kesenian

3. Menjaga martabat penerima manfaat

4. Membina relasi dan kedekatan

5. Memberikan peluang partisipasi penerima manfaat dalam mengungkapkan perasaannya.

d. Bimbingan keterampilan kerja

Dalam bimbingan keterampilan kerja ini akan diberikan sesuai dengan minat dan bakat yang dimiliki oleh penerima pelayanan. tujuannya adalah untuk mempersiapkan mereka menghadapi dunia kerja yang selain membutuhkan sikap dan kepribadian yang baik juga harus didukung oleh keterampilan.

Banyak upaya yang dilakukan pemerintah untuk menangani remaja putus sekolah. Salah satunya adalah dengan memberikan pelayanan sosial sistem panti melalui Pelayanan Sosial Bina Remaja (PSBR). Setiap provinsi di Indonesia memiliki PSBR yang berada di bawah naungan Dinas Sosial Provinsi. Dalam Buku Standar Pelayanan Sosial PSBR yang diterbitkan oleh Direktorat Pelayanan Sosial Anak (2008) mengatakan bahwa PSBR memiliki peranan atau tugas yaitu memberikan perlindungan, pelayanan, dan rehabilitasi sosial bagi penyandang masalah kesejahteraan sosial remaja putus sekolah terlantar. Tujuan pelayanan sosial di PSBR adalah untuk memperbaiki 
keberfungsian sosial remaja putus sekolah agar nantinya mereka dapat memenuhi kebutuhan mereka dan keluarga tanpa harus bergantung dengan orang lain.

Dalam memberikan pelayanan sosial bagi remaja putus sekolah tentulah tidak mudah. Seorang pekerja sosial harus mampu mendampingi dan membantu remaja putus sekolah dalam memecahkan permasalahan yang mereka hadapi selama proses pelayanan sosial agar pelayanan sosial yang diberikan kepada remaja putus sekolah dapat sesuai dengan kebutuhannya.

Tujuan pemberian pelayanan sosial bagi remaja putus sekolah adalah untuk membantu memperbaiki keberfungsian sosial remaja putus sekolah dan mempersiapkan remaja putus sekolah untuk masuk ke dalam dunia kerja, agar mereka mampu memenuhi kebutuhan mereka secara mandiri tanpa bergantung kepada orang lain. Selain itu juga, dengan adanya pelayanan sosial bagi remaja putus sekolah, diharapkan dapat membantu mengurangi tingkat pengangguran di Indonesia.

\section{PENUTUP}

Pemberian pelayanan sosial kepada remaja putus sekolah, harus dilakukan sesuai dengan dengan tahap-tahap yang ada. Tahap-tahap tersebut dapat mempermudah para pekerja sosial dalam menentukan treatment apa yang akan diberikan kepada remaja putus sekolah. Dalam memberikan pelayanan sosial bagi remaja putus sekolah, harus disesuaikan dengan kebutuhan remaja, sehingga pelayanan sosial yang diberikan dapat bermanfaat dan berguna bagi remaja tersebut.

Pelayanan sosial bagi remaja putus sekolah tentunya sangat diperlukan agar remaja tersebut tetap dapat melaksanakan tugasnya di masyarakat sesuai dengan perannya. Selain itu juga, pelayanan sosial bagi remaja putus sekolah dapat membantu mereka untuk memenuhi kebutuhannya secara mandiri tanpa harus bergantung kepada orang lain.

Ketika remaja putus sekolah yang telah mendapatkan pelayanan sosial telah mampu melaksanakan tugasnya secara baik di masyarakat dan mandiri dalam memenuhi kebutuhannya, maka pelayanan sosial tersebut dikatakan berhasil. Namun sebaliknya, ketika remaja putus sekolah yang telah mendapatkan pelayanan sosial belum mampu melaksanakan perannya dimasyarakat dan belum dapat memenuhi kebutuhannya secara mandiri, berarti terdapat kesalahan pada pelaksanaan pelayanan sosialnya ataupun terhadap remaja itu sendiri.

\section{DAFTAR PUSTAKA}

Cole, L. (1963). Psychology Of Adolescence. 5 Edition. New York : Holt Rinehard and Winston Inc. Dariyo, Agoes.2004. Psikologi Perkembangan Remaja. Bogor Selatan: Ghalia Indonesia.

Direktorat Jenderal Pelayanan dan Rehabilitasi Sosial. Direktoral Pelayanan

Sosial Anak. Depsos RI. (2008). Standar Pelayanan Sosial Panti Sosial Bina Remaja (PSBR). Jakarta.

Hurlock, Elisabeth. 1980, Psikologi perkembangan : Suatu Pendekatan Sepanjang Rentang Kehidupan, Jakarta : Erlangga

Kusumah, Inu Hardi. 2008. Model Kewiraswastaan Bidang Jasa Keterampilan Otomotif. Universitas Pendidikan Indonesia. Bandung.

Santrock, John W. 2003. Adolescence Perkembangan Remaja. Erlangga. Jakarta

Soetarso. 1997. Kesejahteraan Sosial, Pelayanan Sosial dan Kebijakan Sosial . Bandung : STKS

Wibhawa, Budhi, dkk. 2010. Dasar-Dasar Pekerjaan Sosial. Bandung : Widya Padjadjaran.

Widodo,Nurdin Dkk. 2012. Evaluasi Pelaksanaan Rehabilitas Sosial Pada Panti Sosial : Pembinaan

Lanjut (After Care Services) Pasca Rehabilitas Sosial. P3KS Press (Anggota IKAPI). Jakarta www.bps.go.id (diunduh pada 2 November 2011 pukul 15.09) 